\title{
Liver Cancer Pathologic Primary Tumor TNM Finding v6
}

National Cancer Institute

\section{Source}

National Cancer Institute. Liver Cancer Pathologic Primary Tumor TNM Finding v6. NCI

Thesaurus. Code C61166.

A pathologic finding about one or more characteristics of liver cancer, following the rules

of the TNM AJCC v6 classification system as they pertain to staging of the primary

tumor. TNM pathologic primary tumor findings are based on clinical findings

supplemented by histopathologic examination of one or more tissue specimens acquired during surgery. 